Article

\title{
Punicalagin Content and Antifungal Activity of Different Pomegranate (Punica ganatum L.) Genotypes
}

\author{
Domenico Rongai ${ }^{1}{ }^{*}$, Patrizio Pulcini ${ }^{1}$, Giovanni Di Lernia ${ }^{1}$, Paolo Nota ${ }^{1}$, Pjerin Preka ${ }^{2}$ and \\ Filomena Milano ${ }^{1}$ \\ 1 CREA-DC Research Centre for Plant Protection and Certification, via C.G Bertero, 22, 00156 Rome, Italy \\ 2 CREA-OFA Research Centre for Olive, Citrus and Tree fruit, Via di Fioranello, 52, 00134 Rome, Italy \\ * Correspondence: domenico.rongai@crea.gov.it
}

Received: 16 May 2019; Accepted: 1 July 2019; Published: 16 July 2019

check for updates

\begin{abstract}
This study investigated the antifungal activity of a number of pomegranate genotypes. Since the main compound of pomegranate extract is punicalagin, an important substance involved in antifungal and antimicrobial activity, we analyzed the contents of punicalagin ( $\alpha$ and $\beta$ ) in 21 different pomegranate genotypes. Ellagic acid content, total phenolic content, acidity and $\mathrm{pH}$ were also determined. This work allowed us to determine which genotypes of pomegranate can be used to obtain extracts with the highest content of punicalagin, with the goal of developing a green alternative to synthetic pesticides. To improve the extraction system from pomegranate peel fruits, several different solvents were tested. All the pomegranate genotypes tested showed antifungal activity; some genotypes were able to almost completely inhibit the fungus, while others had very low inhibitory activity. Research results also showed that the use of water as a solvent for extraction is very effective, especially when it is combined with ethanol. This is very important for the practical use of the extracts since water is economical and environmentally friendly. The research showed that among the genotypes there is also great variability regarding the chemical parameters. Genotypes with a high phenolic and punicalagin content were significantly correlated with antifungal activity. All the other chemical parameters ( $\mathrm{pH}$, titratable acidity and ellagic acid content) were not correlated with antifungal activity. The results obtained indicate that the fruits of some pomegranate genotypes could be used to obtain extracts very rich in punicalagins and that these substances could be used as an alternative to synthetic products to control plant disease and improve the quality of the plant products, avoiding the impact of synthetic chemicals on the environment.
\end{abstract}

Keywords: pomegranate; Punica granatum; genotypes; total phenol content; punicalagin; ellagic acid; antifungal activity

\section{Introduction}

Punicalagin is an ellagitannin, a type of hydrolysable tannin with a high molecular weight. It is found in alpha and beta forms in plants of the genera Myrtales such as Terminalia catappa, Terminalia myriocarpa and Punica granatum (pomegranate). Pomegranates are mainly cultivated in the Mediterranean area, Southern Asia and in several countries of North and South America. Recently, the pomegranate has attracted increasing attention due to its high content of polyphenols such as punicalin, punicalagin, ellagic acid and anthocyanins, mainly located in the fruit peel, mesocarp and aril [1]. These compounds may have human health benefits due to their strong radical scavenging and antioxidant ability [2-6], and antibacterial and antifungal activity [7-10].

These strong antioxidant pomegranate properties play a key protective role not only in human health, but also against fruit decay caused by pathogens during growth and storage, such as Aspergillus 
niger, Penicillium spp., Alternaria spp., Nematospora spp., Coniella granati, Pestalotiopsis versicolor and mostly Botrytis cinerea [11]. Synthetic fungicides, such as fludioxonil, have extensively minimized pre-and post-harvest sepsis damage from these pathogens. However, severe problems associated with fungicide usage, including tolerant pathogen strains and health/environmental concerns, have rendered necessary a search for alternate pathogen control approaches. Several innovative treatments, such as organic acids and derivatives (oxalic acid, salicylates and jasmonates), as well as polyamines, among others, have been examined in this aspect, as they could account for the maintenance of membrane integrity and fluidity against environmental stress and pathogen fruit decay [12,13].

An alternative strategy to synthetic pesticides to control fungus and bacteria in the crop could be the use of environmentally-friendly natural formulations [14-16]). Punica granatum peel extract is an important source of bioactive compounds and its antimicrobic activity is linked to a high level of phenolic and flavonoid content $[6,17]$. The compound punicalagin isolated from the peel showed the same antifungal activity as the crude extract [18]. The lack of difference between extract and pure substance is probably due to the fact that the punicalagin is, as noted above, the main substance in pomegranate fruit peel (about $216.8 \mathrm{mg} \mathrm{g}^{-1} \mathrm{DW}$ ). The importance of punicalagin in antifungal activity has been studied Rongai et al. [10]. They hypothesized a possible mechanism for its antifungal activity. By means of computational chemistry approaches, they showed that punicalagin and amphotericin B are characterized by similar molecular interaction properties, probably connected to their ability to form pore-like aggregates in the cellular membranes of fungi.

Regarding the choice of the most suitable solvent for the extraction of these substances from the peel of the pomegranate, an aqueous solvent showed a higher extractive efficiency than acetone, petroleum, ethyl acetate and toluene [6]. Antifungal tests of $P$. granatum peel extracts obtained from water, ethanol, methanol and propanol did not show any significant difference between the solvents used for the extraction procedures except for propanol extract where the effectiveness was slightly lower [9].

Total polyphenolic content (TPC) in pomegranate fruit peel depends on variety. TPC and antioxidant capacity were significantly different among Italian, Israeli and Moroccan genotypes [19,20]. TPC was significantly different between eight cultivars of pomegranate grown in Croatia [21]. Moreover, the stability and concentration of these bioactive compounds were also affected by climatic conditions, maturity, irrigation and fertilization [22].

The aim of our research was to study the antifungal activity of some genotypes of pomegranate. Since the main compound of pomegranate extract is punicalagin, one of the most important substances involved in antifungal and antimicrobial activity, we investigated the correlation between a number of pomegranate genotypes and punicalagin $(\alpha$ and $\beta$ ) content.

Ellagic acid content, total phenolic content, acidity and $\mathrm{pH}$ were also determined. This work allowed us to determine which genotypes of pomegranate could be used to obtain extracts with the highest content of punicalagin, with the ultimate goal of developing a green alternative to synthetic pesticides. Finally, to improve the extraction system from pomegranate peel fruits, several different solvents were tested.

\section{Materials and Methods}

\subsection{Plants Used for Extraction and Fungus}

Twenty different genotypes of Punica granatum were kindly provided by the botanical garden at Research Centre for Olive, Citrus and Tree fruit (CREA-OFA), Rome, Italy, in addition to the commercial cultivar, "Wonderful". Nine genotypes were from the Mediterranean area and twelve from the Middle East. Most genotypes were wild, only four of them were commercial varieties. Of the 21 genotypes used in the trial, six were sweet and fifteen were sour (Table 1). Fruits were picked in mid-October when a yellow-pink or red color appeared. The fungus Fusarium oxysporum f. s.p. lycopersici (strain CRA-PAV collection n. ER1372) was used. It was maintained on potato dextrose agar (PDA, OXOID 
CM 0139) and stored at $4{ }^{\circ} \mathrm{C}$. When needed, the isolate was grown for 8 days on PDA in the dark at 25 $\pm 2{ }^{\circ} \mathrm{C}$.

Table 1. Geographic origins, pomegranate type and pomegranate juice of 20 genotypes of Punica granatum collected at the Research Centre for Olive, Citrus and Tree fruit (CREA-OFA), and of "Wonderful", a commercial cultivar.

\begin{tabular}{cccc}
\hline Genotype Code & Geographic Origins & Pomegranate Type & Pomegranate Juice \\
\hline Wonderful & Middle Eastern & Commercial & Sour/Sweet \\
CREA-FRU 1 & Mediterranean & Wild & Sweet \\
CREA-FRU 2 & Middle Eastern & Wild & Sour \\
CREA-FRU 3 & Middle Eastern & Wild & Sour \\
CREA-FRU 4 & Middle Eastern & Wild & Sour \\
CREA-FRU 6 & Middle Eastern & Wild & Sour \\
CREA-FRU 7 & Middle Eastern & Wild & Sour \\
CREA-FRU 9 & Middle Eastern & Wild & Sour \\
CREA-FRU 10 & Mediterranean & Wild & Sour \\
CREA-FRU 11 & Middle Eastern & Wild & Sour \\
CREA-FRU 12 & Mediterranean & Wild & Sweet \\
CREA-FRU 18 & Middle Eastern & Wild & Sour \\
CREA-FRU 24 & Middle Eastern & Wild & Sour \\
CREA-FRU 70 & Mediterranean & Commercial & Sweet \\
CREA-FRU 71 & Mediterranean & Commercial & Sweet \\
CREA-FRU 72 & Middle Eastern & Wild & Sweet \\
CREA-FRU 73 & Mediterranean & Commercial & Sweet \\
CREA-FRU 74 & Mediterranean & Wild & Sour \\
CREA-FRU 75 & Mediterranean & Wild & Sour \\
CREA-FRU 76 & Mediterranean & Wild & Sour \\
CREA-FRU 206 & Middle Eastern & Wild & Sour/Sweet \\
\hline
\end{tabular}

\subsection{Preparation of Powders and Extracts}

The extract powder was obtained according to the method described by Rongai et al. [9]. Sixty g of pomegranate peel $\mathrm{cv}$ Wonderful were added to $500 \mathrm{~mL}$ of each of the following solvents: methanol (extra pure, SLR Carlo Erba Reagents, Milan, Italy), water (bidistilled water from a Milli-Q-System, Millipore, Bedford, UK), ethanol (analytical grade RPE, Carlo Erba Reagents, Milan, Italy), and water/ethanol $(80 \%, 40 \%$ and $20 \%, v / v)$.

For all other varieties, an extract was obtained using water mixed with $20 \%$ ethanol. The mixture (solvent and pomegranate pieces) was agitated overnight in a magnetic stirrer at $40^{\circ} \mathrm{C}$, before sonicating at $80 \%$ amplitude for $15 \mathrm{~min}$ ( $3 \mathrm{~s}$ on and $7 \mathrm{~s}$ off) (Ney 300 Ultrasonic Bath, New York, NY, USA). The solvents were vacuum evaporated in a rotary evaporator (Büchi R-210 Rotavapor, Flawil, Switzerland). The extracts obtained with methanol (ME), water (WE), ethanol (EE), $80 \%$ water and $20 \%$ ethanol (PAEE80-20), 40\% water and 60\% ethanol (PAEE40-60), and 20\% water and 80\% ethanol (PAEE20-80), were first centrifuged at $2279 \mathrm{~g}$ for $10 \mathrm{~min}$ at room temperature (Allegra $21 \mathrm{R}$, Beckman Coulter, Milan, Italy). The supernatant was filtered through $0.45 \mu \mathrm{m}$ polytetrafluoroethylene (PTFE), then frozen at $-80{ }^{\circ} \mathrm{C}$ for $24 \mathrm{~h}$ and finally lyophilized in a freeze dryer for 2 days. The powders of the extracts obtained were stored in a freezer at $-20^{\circ} \mathrm{C}$ for further assays.

\subsection{Mycelial Growth Inhibition Assay}

The pomegranate peel extracts ME, WE, EE, PAEE80-20, PAEE40-60 and PAEE20-80 were tested in Petri dishes. A total of $200 \mathrm{mg}$ of each extract were added to $19.8 \mathrm{~mL}$ of potato dextrose agar (PDA) and subsequently put into sterile $90 \mathrm{~mm}$ diameter Petri plates. In addition, a plate containing a specific standard fungicide (Marisan 50 PB, Dicloran 60\%, SIAPA s.r.l., Milano, Italy) was used at the concentration of $0.15 \% \mathrm{w} / \mathrm{w}$ to serve as a negative control to determine the effectiveness of the extracts by comparison. PDA with sterile water served as the control. Antifungal activity tests were 
performed by placing $5 \mathrm{~mm}$ mycelial agar discs cut from the actively growing margin of a colony of F. oxysporum in the center of each plate. Four replicates for each extract were set up and the whole experiment was repeated three times. Radial growth was measured at the 4th day after incubation at $25{ }^{\circ} \mathrm{C}$ in the dark. The percentage growth inhibition of each extract was calculated by the formula: $\%$ inhibition $=($ growth in control - growth in sample/growth in control $) \times 100$.

\subsection{Determination of Total Phenolic Content}

Total phenolic content of extracts was determined with Folin-Ciocalteu reagent [23]. A total of $20 \mu \mathrm{L}$ of each extract solution $(0.5 \mathrm{mg} / \mathrm{mL}$ in water) was added to $1.58 \mathrm{~mL}$ of ultra-pure water and $100 \mu \mathrm{L}$ of the Folin-Ciocalteu reagent, mixed well and left for $8 \mathrm{~min}$. Then, $300 \mu \mathrm{L}$ of $2 \%$ sodium carbonate were added, and the cuvettes were shaken and left in the dark for $1 \mathrm{~h}$ at room temperature. Absorbance was measured on a spectrophotometer (Varian Cary 100 Conc UV-Vis) at $\lambda=760 \mathrm{~nm}$ against a blank. Gallic acid was used as a standard phenolic compound to make the calibration curve that ranged from 0 to $500 \mathrm{mg} / \mathrm{L}\left(\mathrm{r}^{2}=0.9913\right)$. The results are expressed as $\mathrm{mg}$ of gallic acid equivalents (GAE) per g of dry weight of lyophilized plant extracts. All measurements were repeated three times,

\subsection{Acidity and $p H$ Analysis}

Acidity was determined by titration method with a $0.01 \mathrm{~N}$ alkaline sodium hydroxide solution, using phenolphthalein $(1 \% \mathrm{w} / \mathrm{w})$ as an indicator. The equivalents of base required $(\mathrm{vol} \times \mathrm{N})$ were used to calculate the acidity of the extracts, and are expressed in meq $\mathrm{NaOH}$ per $\mathrm{g}$ of dry weight of lyophilized plant extracts. The $\mathrm{pH}$ value of each extract was determined with a Hamilton $\mathrm{pH}$ glass electrode sensor on a $1 \% \mathrm{w} / \mathrm{w}$ water solution. All measurements were repeated twice within a period of 10 days.

\subsection{HPLC-UV Analysis of Extracts}

The PAEE (pomegranate water-ethanol-extract) analysis was performed using a VARIAN HPLC system equipped with a ProStar 230 separation module, ProStar PDA 330 UV Detector, ProStar 400 Autosampler, Agilent 1100 series on line Degasser and a Varian Star Workstation 6.00. The HPLC separation was carried out with an RP Kinetex C18 $5 \mu 100 \AA 150 \times 4.6 \mathrm{~mm}$ analytical column operating at $30{ }^{\circ} \mathrm{C}$. The UV-DAD (diode array detector) detector performed monitoring at $280 \mathrm{~nm}$. The mobile phase consisted of water (A) and methanol (B) linear gradient, starting with $90 \%$ A: $10 \%$ B up to 100\% $\mathrm{B}$ in $60 \mathrm{~min}$. The flow rate was constant at $0.9 \mathrm{~mL} \mathrm{~min}^{-1}$. Standard reference materials punicalagin (a mixture of 55\% $\alpha, 45 \% \beta$ ) and ellagic acid (Sigma-Aldrich, St. Louis, MO, USA) were used for identification and quantification with an external standard method. Data acquisition and processing were performed with GALAXIE WS 1.7 software.

\subsection{Statistical Analysis}

AN ANOVA was carried out and mean values were compared by Fisher's protected LSD (Least Significant Difference) test at $P \leq 0.05$. SigmaPlot version SPW10 and Sigma Stat version 3.5 were used to create graphics and the linear regression.

\section{Results Discussion}

\subsection{Mycelial Growth Inhibition Assays}

Mycelial growth on water extract (WE), methanol extract (ME) and ethanol extract (EE) at $4 \mathrm{~d}$ after inoculation were not statistically different: $16.5,16.5$ and $15.5 \mathrm{~mm}$, respectively. Similar values, 15.5, 16 and $15.7 \mathrm{~mm}$, were recorded for PAEE80-20, PAEE40-60 and PAEE20-80, respectively. In contrast, the untreated control had a mycelial growth of $45.7 \mathrm{~mm}$, a statistically much higher value than the extracts (Table 2). 
Table 2. Mycelial growth and extraction efficiency of six different solvent systems: $100 \%$ water (WE), $100 \%$ methanol (WE), 100\% ethanol (EE), 80\% water 20\% ethanol (PAEE $80-20$ ), $40 \%$ water 60\% ethanol (PAEE40-60). Values with different letters for each group are statistically different (LSD test, $P=0.05$ ). Standard deviations of the means are indicated.

\begin{tabular}{cccccc}
\hline \multirow{2}{*}{ Treatment } & Dose & \multicolumn{2}{c}{ Mycelial Growth of F. oxysporum } & \multicolumn{2}{c}{ Extraction Efficiency } \\
\cline { 3 - 5 } & & \multicolumn{2}{c}{ mm } \\
\hline Untreated control & & 45.7 & $\pm 0.41 \mathrm{a}$ \\
Synthetic fungicide & $0.15 \%$ & 17.5 & $\pm 0.64 \mathrm{~b}$ & \\
WE & $1 \%$ & 16.5 & $\pm 0.64 \mathrm{bc}$ & 18.1 & $\pm 0.55 \mathrm{a}$ \\
ME & $1 \%$ & 16.5 & $\pm 0.63 \mathrm{bc}$ & 17.4 & $\pm 0.31 \mathrm{a}$ \\
EE & $1 \%$ & 15.5 & $\pm 0.30 \mathrm{c}$ & 13.8 & $\pm 0.32 \mathrm{~d}$ \\
PAEE80-20 & $1 \%$ & 15.5 & $\pm 0.64 \mathrm{c}$ & 17.4 & $\pm 0.37 \mathrm{a}$ \\
PAEE40-60 & $1 \%$ & 16.0 & $\pm 0.40 \mathrm{c}$ & 16.8 & $\pm 0.23 \mathrm{~b}$ \\
PAEE20-80 & $1 \%$ & 15.7 & $\pm 0.48 \mathrm{c}$ & 16.2 & $\pm 0.14 \mathrm{c}$ \\
& & $F=451.12$ & & $F=24.154$ \\
& & $P<0.001$ & & $P<0.001$ \\
\hline
\end{tabular}

The comparison of pomegranate genotypes showed that all extracts had an antifungal activity at $4 \mathrm{~d}$ after inoculation. The lowest value of fungal growth was recorded for CREA-FRU 6 with $7.5 \mathrm{~mm}$, followed by CREA-FRU 76 and CREA-FRU 11, with values of 9.25 and $9.75 \mathrm{~mm}$, respectively. The values were a little higher for CREA-FRU 10, CREA-FRU 71 and CREA-FRU 75 where the mycelia growth was $12 \mathrm{~mm}$. Good antifungal activity was shown by CREA-FRU 12, CREA-FRU 24, Wonderful, CREA-FRU 72 and CREA-FRU 18, with values of $12.75,13,14.25,14.50$ and $15.5 \mathrm{~mm}$, respectively. Most of the genotypes exhibited fungal growth between 20 to $26 \mathrm{~mm}$, values statistically much lower than the untreated control where about $46 \mathrm{~mm}$ was recorded (Figure 1).

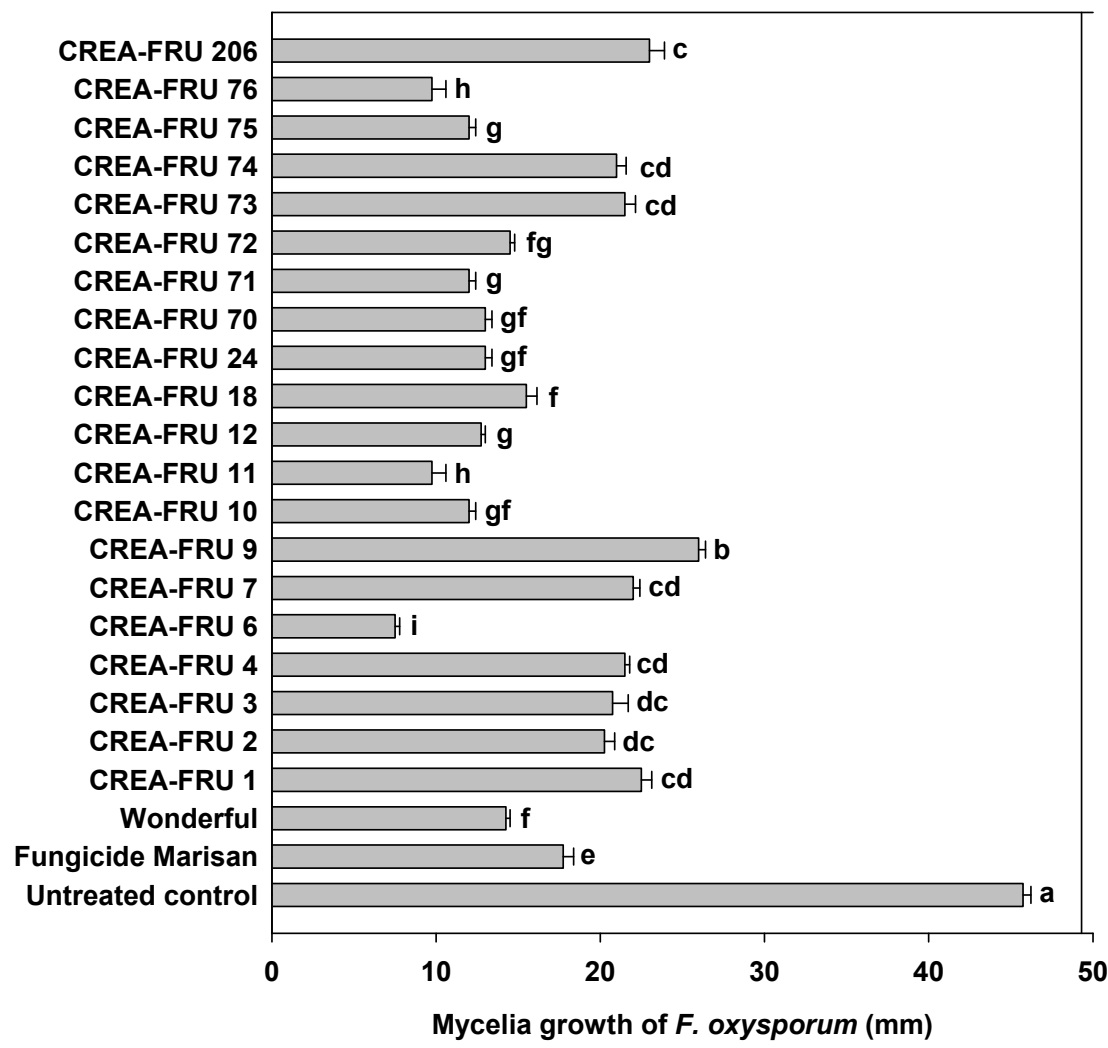

Figure 1. In vitro mycelial growth of F. oxysporum with a dose of $1 \%$ of pomegranate peel aqueous ethanol extract (PAEE80-20) at $4 \mathrm{~d}$ after inoculation. Values with different letters for each group are statistically different (LSD test, $P=0.05$ ). Standard deviations of the means are indicated. 


\subsection{Solvent Extraction Efficiency}

Total extract yields (Table 1), reported as percentage of $\mathrm{g}$ of extract per $100 \mathrm{~g}$ pomegranate fresh peel ( $61 \%$ water content), demonstrated that the extraction system using water and methanol as solvents showed similar values $(18.1 \%$ and $17.4 \%$, respectively), that were statistically higher than ethanol (13.8\%).

These results are in partial agreement with some authors [20,24]. In fact, they reported that methanol and water were more efficient than the ethanol solvent but that the pomegranate peel extracted with methanol gave a yield slightly higher than that obtained with water.

The use of three different concentrations of ethanol in water showed similar values between PAEE80-20 (17.4\%) and PAEE40-60 (16.6\%), while for PAEE20-80 a value of 16.2\% was recorded, statistically lower than PAEE80-20 (Table 2). Thus, the addition of water to the ethanol solvent increased the extraction efficiency of the solvent. The ethanol and water combination could have led to higher penetration into the pomegranate peel tissue than that caused by single components. The presence of water in the ethanol solvent may increased penetrationin to pores and crevices in the peel particles, thus enlarging the surface area for greater contact with the solvent [25].

\subsection{Total Phenolic, Punicalagin Content, Ellagic Acid Content, Acidity, $\mathrm{pH}$ and Correlation Analysis}

The amount of total phenolic content (TPC), ellagic acid content (EA) and punicalagin content (PC) varied widely among the pomegranate genotypes. TPC, expressed as $\mathrm{mg} \mathrm{GAE}^{-1} \mathrm{DW}$, ranged from 146.0 in CREA-FRU 9 to 612.7 in CREA-FRU 6. (Table 3).

Table 3. Chemical analysis of extracts of 20 genotype of Punica granatum collected at the "CREA Research Center for Olive, Citrus and Tree Fruits" (Italy), and compared with "Wonderful” a commercial cultivar of Punica granatum. TPC = total phenolic content; EA = ellagic acid; PC = punicalagin content. Values with different letters for each column are statistically different (LSD test, $P=0.05$ ).

\begin{tabular}{|c|c|c|c|c|c|c|c|}
\hline \multirow{2}{*}{ Genotype Code } & \multirow{2}{*}{$\mathrm{pH}$} & \multirow{2}{*}{ Acidity } & \multirow{2}{*}{ TPC } & \multirow{2}{*}{ EA } & \multicolumn{3}{|c|}{ PC } \\
\hline & & & & & $P C(\alpha+\beta)$ & $\mathbf{P} \alpha \mathbf{C}$ & $\mathbf{P} \beta C$ \\
\hline & & $\begin{array}{c}\text { meq } \mathrm{NaOH} \\
\mathrm{g}^{-1} \mathrm{DW}\end{array}$ & $\begin{array}{c}\text { mg GAE } \\
\mathrm{g}^{-1} \mathrm{DW}\end{array}$ & $\stackrel{\text { mg }}{\mathrm{g}^{-1} \mathrm{DW}}$ & $\underset{\mathrm{g}^{-1} \mathrm{DW}}{\mathrm{mg}}$ & $\stackrel{\text { mg }}{\mathrm{g}^{-1} \mathrm{DW}}$ & $\underset{g^{-1} \mathrm{DW}}{\mathrm{mg}}$ \\
\hline Wonderful & $4.07 \mathrm{a}$ & $1.38 \mathrm{e}$ & $432.7 \mathrm{c}$ & $14.6 \mathrm{~d}$ & $216.8 \mathrm{c}$ & $95.1 \mathrm{c}$ & $121.3 \mathrm{c}$ \\
\hline CREA-FRU 1 & $4.24 \mathrm{a}$ & $1.11 \mathrm{f}$ & $241.6 \mathrm{e}$ & $6.1 \mathrm{~g}$ & $176.9 \mathrm{~d}$ & $38.1 \mathrm{f}$ & $138.8 \mathrm{c}$ \\
\hline CREA-FRU 2 & $4.12 \mathrm{a}$ & $1.60 \mathrm{de}$ & $261.0 \mathrm{e}$ & $9.6 \mathrm{f}$ & $87.8 \mathrm{f}$ & $19.6 \mathrm{~g}$ & $68.2 \mathrm{f}$ \\
\hline CREA-FRU 3 & $4.18 \mathrm{a}$ & $1.30 \mathrm{e}$ & $444.3 \mathrm{c}$ & $9.0 \mathrm{f}$ & $144.3 \mathrm{de}$ & $35.3 \mathrm{f}$ & $109.0 \mathrm{~d}$ \\
\hline CREA-FRU 4 & $4.19 \mathrm{a}$ & $1.75 \mathrm{~cd}$ & $311.0 \mathrm{~d}$ & $7.4 \mathrm{~g}$ & $97.8 \mathrm{f}$ & $24.4 \mathrm{~g}$ & $73.4 \mathrm{e}$ \\
\hline CREA-FRU 6 & $3.92 \mathrm{ab}$ & $2.90 \mathrm{a}$ & $612.7 \mathrm{a}$ & $7.5 \mathrm{~g}$ & $476.7 \mathrm{a}$ & $120.6 \mathrm{~b}$ & $356.1 \mathrm{a}$ \\
\hline CREA-FRU 7 & $4.15 \mathrm{a}$ & $1.80 \mathrm{c}$ & $402.8 \mathrm{c}$ & $10.0 \mathrm{f}$ & $169.4 \mathrm{~d}$ & $34.4 \mathrm{f}$ & $135.0 \mathrm{c}$ \\
\hline CREA-FRU 9 & $3.90 \mathrm{ab}$ & $1.65 \mathrm{~d}$ & $146.0 \mathrm{f}$ & $0.6 \mathrm{i}$ & 1.61 & $1.3 \mathrm{i}$ & $0.3 \mathrm{i}$ \\
\hline CREA-FRU 10 & $3.69 \mathrm{~b}$ & $3.15 \mathrm{a}$ & $529.3 \mathrm{~b}$ & $27.3 \mathrm{~b}$ & $318.9 \mathrm{~b}$ & $128.7 \mathrm{~b}$ & $190.15 b$ \\
\hline CREA-FRU 11 & $4.02 \mathrm{a}$ & $2.65 \mathrm{~b}$ & $514.9 \mathrm{~b}$ & $6.0 \mathrm{~g}$ & $369.2 \mathrm{~b}$ & $183.8 \mathrm{a}$ & $185.4 \mathrm{~b}$ \\
\hline CREA-FRU 12 & $3.93 \mathrm{ab}$ & $1.25 \mathrm{e}$ & $448.0 \mathrm{c}$ & $40.1 \mathrm{a}$ & $145.6 \mathrm{de}$ & $78.9 \mathrm{~d}$ & $66.7 \mathrm{f}$ \\
\hline CREA-FRU 18 & $3.75 \mathrm{~b}$ & $2.35 \mathrm{bc}$ & $448.7 \mathrm{c}$ & $8.5 \mathrm{fg}$ & $118.4 \mathrm{e}$ & $50.0 \mathrm{e}$ & $68.5 \mathrm{f}$ \\
\hline CREA-FRU 24 & $3.92 \mathrm{ab}$ & $1.45 \mathrm{e}$ & $514.4 \mathrm{~b}$ & $15.4 \mathrm{~d}$ & $130.1 \mathrm{e}$ & $75.2 \mathrm{~d}$ & $46.4 \mathrm{~g}$ \\
\hline CREA-FRU 70 & $3.92 \mathrm{ab}$ & $1.75 \mathrm{~cd}$ & $347.2 \mathrm{~d}$ & $18.0 \mathrm{c}$ & $69.3 \mathrm{~g}$ & $29.7 \mathrm{fg}$ & $39.6 \mathrm{~g}$ \\
\hline CREA-FRU 71 & $4.04 \mathrm{a}$ & $1.85 \mathrm{c}$ & $572.3 \mathrm{a}$ & $12.3 \mathrm{e}$ & $254.9 \mathrm{c}$ & $91.8 \mathrm{c}$ & $163.1 \mathrm{bc}$ \\
\hline CREA-FRU 72 & $4.01 \mathrm{a}$ & $1.7 \mathrm{~d}$ & $510.5 \mathrm{~b}$ & $10.8 \mathrm{f}$ & $128.6 \mathrm{e}$ & $60.5 \mathrm{e}$ & $68.1 \mathrm{f}$ \\
\hline CREA-FRU 73 & $3.90 \mathrm{ab}$ & $1.65 \mathrm{~d}$ & $237.7 \mathrm{e}$ & $4.6 \mathrm{~h}$ & $4.9 \mathrm{i}$ & $3.8 \mathrm{~h}$ & $0.5 \mathrm{i}$ \\
\hline CREA-FRU 74 & $3.88 \mathrm{ab}$ & $1.60 \mathrm{de}$ & $295.5 \mathrm{de}$ & $7.0 \mathrm{~g}$ & $92.0 \mathrm{f}$ & $57.7 \mathrm{e}$ & $37.3 \mathrm{~g}$ \\
\hline CREA-FRU 75 & $3.92 \mathrm{ab}$ & $2.00 \mathrm{c}$ & $585.8 \mathrm{a}$ & $31.3 \mathrm{~b}$ & $319.9 \mathrm{~b}$ & $129.3 \mathrm{~b}$ & $190.4 b$ \\
\hline CREA-FRU 76 & $4.02 \mathrm{a}$ & $2.65 \mathrm{~b}$ & $514.9 \mathrm{~b}$ & $37.8 \mathrm{a}$ & $453.6 \mathrm{a}$ & $128.5 \mathrm{~b}$ & $325.1 \mathrm{a}$ \\
\hline CREA-FRU 206 & $4.03 \mathrm{a}$ & $1.35 \mathrm{e}$ & $249.6 \mathrm{e}$ & $8.2 \mathrm{fg}$ & $25.9 \mathrm{~h}$ & $21.6 \mathrm{~g}$ & $4.3 \mathrm{~h}$ \\
\hline
\end{tabular}

Using regression analyses, the relationship between TPC content in each pomegranate genotype tested and the percentage of mycelial growth of fungus (Table 4) showed a correlation $\left(R^{2}=0.77\right)$. This is because polyphenol compounds are usually the major antifungal compounds of most plant extracts [26-28]. In most of the genotypes tested, TPC was positively related with antifungal activity, except for CREA-FRU 3 and CREA-FRU 7. They, in fact, showed a low antifungal activity with mycelial 
growth over $20 \mathrm{~mm}$ (Figure 1) but high values (over $400 \mathrm{mg} \mathrm{GAE} \mathrm{g}^{-1} \mathrm{DW}$ ) of phenolic content (Table 3). The low antifungal activity of CREA-FRU 3 and CREAM-FRU 7 could be because they have low values of titratable acidity as reported in Table 4 . These results agree with those by others $[29,30]$ who reported that inhibitory effects were higher when polyphenols were in combination with organic acids.

Table 4. Correlation matrix of mycelia growth (MG); punicalagin content ( $\mathrm{PC}, \mathrm{P}_{\alpha} \mathrm{C}$ and $\mathrm{P}_{\beta} \mathrm{C}$ ); ellagic acid (EA); total phenol content (TPC); titratable acidity (TA) and $\mathrm{pH}$. Absolute linear correlation coefficients $\mathrm{R}^{2}$ are reported.

\begin{tabular}{ccccccc}
\hline & MG & PC & EA & TPC & TA & pH \\
\hline pH & 0.13 & 0.01 & 0.24 & 0.50 & 0.26 & \\
TA & 0.38 & 0.56 & 0.07 & 0.30 & & \\
TPC & 0.77 & 0.61 & 0.08 & & & \\
EA & 0.32 & 0.09 & & & & \\
PC & 0.61 & & & & & \\
$\mathrm{P}_{\alpha} \mathrm{C}$ & 0.81 & & & & & \\
$\mathrm{P}_{\beta} \mathrm{C}$ & 0.60 & & & & & \\
MG & & & & & & \\
\hline
\end{tabular}

The PC analyses carried out on pomegranate genotypes (Table 3) showed that the lowest values were recorded with genotypes CREA-FRU 9 (1.6 $\left.\mathrm{mg} \mathrm{g}^{-1} \mathrm{DW}\right)$, CREA-FRU 73 (4.9) and CREA-FRU206 (25.9), while the highest values were recorded with CREA-FRU $6\left(476.7 \mathrm{mg} \mathrm{g}^{-1} \mathrm{DW}\right)$ and CREA-FRU 76 (453.6). The PC content in all genotypes and the percentage of mycelial growth of $F$. oxysporum showed a correlation of $\mathrm{R}^{2}=0.61$. More specifically, the $\alpha$ anomer of punicalagins $\left(\mathrm{P}_{\alpha} \mathrm{C}\right)$ showed an $R^{2}=0.81$, higher than 0.60 recorded for the $\beta$ anomer $\left(P_{\beta} C\right)$ (Table 4). The higher correlation with $\mathrm{P}_{\alpha} \mathrm{C}$ could be due to the better spatial arrangement of this anomer for interaction with the fungal cell wall. This is in accordance with Rongai et al. [10], who reported that punicalagins can form pore-like structures in which the inner wall is formed by the glucoside unit, and the outer wall is formed by the lasting moieties including the ellagic acid, all of which may alter the physiological transmembrane gradients and lead to cell death. A correlation $\left(R^{2}=0.61\right)$ was found between PC and TPC.

EA content varied from $0.6 \mathrm{mg} \mathrm{g}^{-1} \mathrm{DW}$ in CREA-FRU 9 to $40.1 \mathrm{mg} \mathrm{g}^{-1} \mathrm{DW}$ in CREA-FRU 12. The lowest value of EA content corresponded to the highest value of mycelia growth but the genotypes with the highest values of EA such as CREA-FRU 12 or CREA-FRU 10 did not have the lowest levels of mycelial growth (Table 3, Figure 1). There was no correlation between ellagic acid content and mycelial growth of $F$. oxysporum. IN addition, there was no linear correlation between mycelial growth and the other chemical parameters (Table 4). These findings are in general agreement, at least in part, with some previous studies, which reported no linear correlation between EA content and TPC, and confirmed that EA might not be the dominant component responsible for the biological activity of pomegranate extract [31].

Regarding the titratable acidity and $\mathrm{pH}$ values, the genotypes CREA-FRU 1 and CREA-FRU 4 showed high values (4.24 and 4.19) of $\mathrm{pH}$ and low values (1.11 and 1.75) of titrable acidity, respectively. In contrast, genotypes CREA-FRU 10 and CREA-FRU 18 showed lower $\mathrm{pH}$ values (3.69 and 3.75) and higher titratable acidity values (3.15 and 2.35), respectively. There was no apparent relationship between mycelial growth and any other chemical parameter (Table 3). However, in Table 2 and Figure 1, the genotypes with the highest inhibition of mycelial growth (CREA-FRU 6, CREA-FRU 11 and CREA-FRU 76) had high values of TPC and titrable acidity. These results are in accordance with those reported by Orak et al. [29] who noted that a pomegranate genotype with low antifungal activity had a high value of TPC but a low value of titrable acidity.

\section{Conclusions}

All the pomegranate genotypes tested showed antifungal activity; however, this inhibitory activity was variable, some genotypes were able to almost completely inhibit the fungus, while others had very 
low inhibitory activity. This allowed us to identify the best pomegranate genotypes that could be used as a source for the extraction of bioactive components. The results also showed that the use of water as a solvent for extraction was very effective, especially when it was combined with ethanol. This is very important for the practical use of the extracts as water is economical and environmentally friendly.

Research showed that among the genotypes there was also great variability in their chemical parameters. Genotypes with a high phenolic and punicalagin content were significantly correlated with antifungal activity, while those that had a very low content of polyphenols and punicalagins had a low inhibitory activity. All of the other chemical parameters $(\mathrm{pH}$, titratable acidity and ellagic acid content) were not correlated with antifungal activity.

To conclude, our results indicate that the pomegranate peel of the wild genotypes CREA-FRU6, CREAFRU11 and CREAM-FRU76 had a strong antifungal activity, as well as high levels of total phenol and punicalagin contents. The study suggests that the fruits of these genotypes could be used to obtain extracts very rich in $\alpha$-punicalagin, the main component of the bioactivity of the pomegranate plant. These substances could be used as an alternative to synthetic products to control plant disease and improve the quality of vegetable products, avoiding the impact of chemicals on the environment.

Author Contributions: D.R. wrote the paper. P.P. (Patrizio Pulcini), P.P. (Pjerin Preka) and F.M. contributed advice and reagents/materials/analysis tools. D.R. and G.D.L. performed the experiments. D.R., P.N. and P.P. (Patrizio Pulcini) conceived and designed the experiments. D.R. and P.P. (Patrizio Pulcini) analyzed the data. D.R., P.P. (Pjerin Preka), G.D.L., P.N. and F.M. read and edited the paper.

Funding: This research received no external funding.

Acknowledgments: This work was supported by the projects "Salvaguardia e valorizzazione del patrimonio olivicolo italiano con azioni di ricerca nel settore della difesa fitosanitaria (SALVAOLIVI)", financed by the Ministry of Agricultural, Food and Forestry Policies.

Conflicts of Interest: The authors declare no conflict of interest.

\section{References}

1. Ulrike, A.F.; Reinhold, C.; Dietmar, R.K. Identification and quantification of phenolic compounds from pomegranate (Punica granatum L.) peel, mesocarp, aril and differently produced juices by HPLC-DAD-ESI/MS(n). Food Chem. 2011, 127, 807-821.

2. Scalbert, A.; Williamson, G. Dietary intake and bioavailability of polyphenols. J. Nutr. 2000, 130, $2073-2085$. [CrossRef] [PubMed]

3. Gill, N.S.; Dhawan, S.; Jain, A.; Arora, R.; Bali, M. Antioxidant and anti-ulcerogenic activity of wild Punica granatum ethanolic seed extract. Res. J. Med. Plants 2012, 6, 47-55. [CrossRef]

4. Malik, A.; Mukhtar, H. Prostate cancer prevention through pomegranate fruit. Cell Cycle 2006, 5, 371-373. [PubMed]

5. Sturgeon, S.R.; Ronnenberg, A.G. Pomegranate and breast cancer: Possible mechanisms of prevention. Nutr. Rev. 2010, 68, 122-128. [CrossRef]

6. Kaneria, M.J.; Chanda, S.V. The effect of sequential fractionation technique on the various efficacies of pomegranate (Punica granatum L.). Food Anal. Method. 2013, 6, 164-175. [CrossRef]

7. Quattrucci, A.; Ovidi, E.; Tiezzi, A.; Vinciguerra, V.; Balestra, G.M. Biological control of tomato bacterial speck using Punica granatum fruit peel extract. Crop Prot. 2013, 46, 18-22. [CrossRef]

8. Romanazzi, G.; Smilanick, J.L.; Feliziani, E.; Droby, S. Integrated management of postharvest gray mold on fruits crops. Postharvest Biol. Technol. 2016, 113, 69-76. [CrossRef]

9. Rongai, D.; Pulcini, P.; Pesce, B.; Milano, F. Antifungal activity of pomegranate peel extract against fusarium wilt of tomato. Eur. J. Plant Pathol. 2017, 147, 229-238. [CrossRef]

10. Rongai, D.; Sabatini, N.; Pulcini, P.; Di Marco, C.; Storchi, L.; Marrone, A. Effect of pomegranate peel extract on shelf life of 1 fresh strawberries: Phytochemical analysis, antifungal activity and possible mechanisms involved. J. Food Sci. Technol. 2018, 55, 2702-2711. [CrossRef]

11. Pareek, S.; Valero, D.; Serrano, M. Postharvest biology and technology of pomegranate. J. Sci. Food Agric. 2015, 95, 2360-2379. [CrossRef] [PubMed] 
12. Paschalidis, K.A.; Moschou, P.N.; Toumi, I.; Roubelakis-Angelakis, K.A. Polyamine anabolic/catabolic regulation along the woody grapevine plant axis. J. Plant Physiol. 2009, 166, 1508-1519. [CrossRef] [PubMed]

13. Wang, W.; Paschalidis, K.; Feng, J.C.; Song, J.; Liu, J.H. Polyamine catabolism in plants: A universal process with diverse functions. Front. Plant Sci. 2019, 10, 561. [CrossRef]

14. Landi, L.; Feliziani, E.; Romanazzi, G. Expression of defense genes in strawberry fruits treated with different resistance inducers. J. Agric. Food Chem. 2014, 62, 3047-3056. [CrossRef] [PubMed]

15. Lopez-Reyes, J.G.; Spadaro, D.; Gullinoa, M.L.; Garibaldi, A. Efficacy of plant essential oils on postharvest control of rot caused by fungi on four cultivars of apples in vivo. Flavour Fragr. J. 2010, 25, 171-177. [CrossRef]

16. Nabigol, A.; Morshedi, H. Evaluation of the antifungal activity of the Iranian thyme essential oils on the postharvest pathogens of Strawberry fruits. Afr. J. Biotechnol. 2011, 10, 9864-9869.

17. Rongai, D.; Pulcini, P.; Pesce, B.; Milano, F. Antifungal activity of some botanical extracts on Fusarium oxysporum. Open Life Sci. 2015, 10, 409-416.

18. Foss, S.R.; Nakamura, C.V.; Ueda-Nakamura, T.; Cortez, D.A.G.; Endo, E.H.; Dias Filho, B.P. Antifungal activity of pomegranate peel extract and isolated compound punicalagin against dermatophytes. Ann. Clin. Microbiol. Antimicrob. 2014, 13, 32-38. [CrossRef]

19. Ferrara, G.; Giancaspro, A.; Mazzeo, A.; Giove, S.-L.; Matarrese, A.M.S.; Pacucci, C.; Punzi, R.; Trani, A.; Gambacorta, G.; Blanco, A.; et al. Characterization of pomegranate (Punica granatum L.) genotypes collected in Puglia region, Southeastern Italy. Sci. Hortic. 2014, 178, 70-78. [CrossRef]

20. Hmid, I.; Elothmania, D.; Hanine, H.; Oukablic, A.; Mehinagic, E. Comparative study of phenolic compounds and their antioxidant attributes of eighteen pomegranate (Punica granatum L.) cultivars grown in Morocco. Arab. J. Chem. 2017, 10, 2675-2684. [CrossRef]

21. Radunić, M.; Jukić Špika, M.; Goreta Ban, S.; Gadže, J.; Díaz-Pérez, J.; MacLean, D. Physical and chemical properties of pomegranate fruit accessions from Croatia. Food Chem. 2015, 177, 53-60. [CrossRef] [PubMed]

22. Mphahlele, R.; Fawole, O.A.; Stander, M.A.; Opara, U.L. Preharvest and postharvest factors influencing bioactive compounds in pomegranate (Punica granatum L.). Sci. Hortic. 2014, 178, 114-123. [CrossRef]

23. Slinkard, K.; Singleton, V.L. Total phenol analyses: Automation and comparison with manual methods. Am. J. Enol. Vitic. 1977, 28, 49-55.

24. Wang, Z.; Pan, Z.; Ma, H.; Atungulu, G.G. Extract of phenolics from pomegranate peels. Open Food Sci. J. 2011, 5, 17-25. [CrossRef]

25. Venkataramanamma, D.; Aruna, P.; Singh, R.P. Standardization of the conditions for extraction of polyphenols from pomegranate peel. J. Food Sci. Technol. 2016, 53, 2497-2503. [CrossRef] [PubMed]

26. Anis, Z.; Sulaiman, O.; Hashim, R.; Mehdi, S.H.; Ghalib, R.M. Radical scavenging activity, total phenol content and antifungal activity of Cinnamomum Iners. Wood. Iran. J. Energy Environ. 2012, 3, 74-78. [CrossRef]

27. Ifesan, B.O.T.; Fashakin, J.F.; Ebosele, F.; Oyerinde, A.S. Antioxidant and antimicrobial properties of selected plant leaves. Eur. J. Med. Plants 2013, 3, 465-473. [CrossRef]

28. El-Khateeb, A.Y.; Elsherbiny, E.A.; Tadros, L.K.; Ali, S.M.; Hamed, H.B. Phytochemical analysis and antifungal activity of fruit leaves extracts on the mycelial growth of fungal plant pathogens. J. Plant Pathol. Microbiol. 2013, 4, 199. [CrossRef]

29. Orak, H.H.; Demïrcï, A.Ş.; Gümüş, T. Antibacterial and antifungal activity of pomegranate (Punica granatum L. cv.) peel. Electron. J. Environ. Agric. Food Chem 2011, 10, 1958-1969.

30. Oliveira, C.E.V.; Stamford, T.L.M.; Neto, N.J.G.; Souza, E.L. Inhibition of Staphylococcus aureus in broth and meat broth using synergies of phenolics and organic acids. Int. J. Food Microbiol. 2010, 137, 312-316. [CrossRef] [PubMed]

31. Wang, C.; Shi, L.; Fan, L.; Ding, Y.; Zhao, S.; Liu, Y.; Ma, C. Optimization of extraction and enrichment of phenolics from pomegranate (Punica granatum L.) leaves. Ind. Crops Prod. 2013, 42, 587-594. [CrossRef]

(C) 2019 by the authors. Licensee MDPI, Basel, Switzerland. This article is an open access article distributed under the terms and conditions of the Creative Commons Attribution (CC BY) license (http://creativecommons.org/licenses/by/4.0/). 